\title{
ЄВРОІНТЕГРАЦІЙНІ АСПЕКТИ РОЗВИТКУ РЕПУТАЦІЙНОГО МЕНЕДЖМЕНТУ В УКРАЇНІ ЗА УМОВ ДІДЖИТАЛІЗАЦІї
}

\section{EUROPEAN INTEGRATION ASPECTS OF REPUTATION MANAGEMENT DEVELOPMENT IN UKRAINE UNDER DIGITALIZATION}

\author{
Микитин Олег Зеновійович \\ кандидат технічних наук, доцент, \\ Національний університет «Львівська політехніка» \\ ORCID: https://orcid.org/0000-0001-9016-6757
}

\author{
Mykytyn Oleh \\ Lviv Polytechnic National University
}

\begin{abstract}
Стаття присвячена сутності розвитку репутаційного менеджменту в Україні за умов діджиталізації. Визначено що репутація, діджиталізація є достатньо новими поняттями для економіки нашої країни. Система репутаційного менеджменту покликана залишати підприємство «в тренді», максимізувати його прибуток, мінімізувати витрати тощо. Формувати ефективну систему репутаційного менеджменту сприяє діджиталізація. Досліджено, що вітчизняним керівникам потрібно враховувати, що системи репутаційного менеджменту суттєво відрізняються використанням традиційних методів та цифрових технологій. Запровадження сучасних інфокомунікаційних технологій виступатиме напрямком підвищення рівня репутації підприємств, рівня їх конкурентоспроможності, зростання гнучкості за умов економічної нестабільності, конкурентної боротьби із іноземними підприємствами внаслідок глобалізування (в т.ч. євроінтегрування).
\end{abstract}

Ключові слова: діджиталізація, цифровізація, інформація, розвиток, репутація репутаційний менеджмент, гудвіл, євроінтегрування.

Статья посвящена сущности развития репутационного менеджмента в Украине в условиях диджитализации. Определено, что репутация, диджитализация достаточно новые понятия для экономики нашей страны. Система репутационного менеджмента призвана покидать предприятие «в тренде», максимизировать его прибыль, минимизировать затраты и т.д. Формировать эффрективную систему репутационного менеджмента способствует диджитализация. Исследовано, что отечественным руководителям следует учитывать, что системы репутационного менеджмента существенно отличаются использованием традиционных методов и цифровых технологий. Введение современных инфрокоммуникационных технологий будет выступать направлением повышения уровня репутации предприятий, уровня их конкурентоспособности, роста гибкости в условиях экономической нестабильности, конкурентной борьбы с иностранными предприятиями в результате глобализации (в т.ч. евроинтегрирования).

Ключевые слова: диджитализация, цифровизация, информация, развитие, репутация, репутационный менеджмент, гудвилл, евроинтегрирование.

The article is devoted to the essence of the development of reputation management in Ukraine in digitalization. It is determined that reputation, and digitalization is entirely new concepts for the economy of our country. The modern world is becoming extremely dynamic, constantly being in a state of so-called turbulence. The key drivers of the dynamics in reputation management today are digitalization processes, active development of communication channels, the use of real-time communication, the emergence of new competitors, the transformation of existing business models, and more. The procedures for the formation and development of effective management systems focused on market trends deserve special attention. The reputation management system is designed to leave the company "in trend", maximize its profits, minimize costs, and more. Digitalization contributes to the formation of an effective system of reputation management. Digitalization and digital culture result from active, revolutionary development of modern technologies (innovations) in economics and management. Reputation management through digital technologies (including the Internet) is a practice of forming the public perception of the organization/enterprise, influ- 
encing how people will perceive the organization and its business on the Internet. It has been studied that domestic leaders need to consider that reputation management systems differ significantly in the use of traditional methods and digital technologies. There is a direct relationship between the positive trend in the level of corporate reputation and high sales, profitability, and more. For Ukraine, the development of digitalization processes has real prospects for modernizing the economy, improving the production and technological structure, ensuring active participation in the innovative economy, overcoming the current crisis, etc. The introduction of modern information and communication technologies will increase the reputation of enterprises, their competitiveness, increasing flexibility in conditions of economic instability, competition with foreign enterprises due to globalization (including European integration).

Keywords: digitalization, digitalization, information, development, reputation, reputation management, goodwill, European integration.

Постановка проблеми. Сучасний світ стає надзвичайно високо динамічним, постійно перебуваючи у стані так званої турбулентності. Ключовими рушіями динаміки в репутаційному менеджменті сьогодні виступають процеси діджиталізації, активний розвиток каналів комунікації, застосування зв'язку у режимі «реального часу», поява нових конкурентів, трансформування чинних бізнес-моделей тощо. Зазначена динаміка одночасно виступає викликами та можливостями для українських підприємств, споживачів тощо. Тому актуальною проблемою для вітчизняного бізнесу ефективно використовувати потенційні можливості та реагувати на виклики. Особливої ж уваги заслуговують процедури фрормування і розвитку ефективних систем менеджменту зорієнтованих на ринкові тренди.

Аналіз останніх досліджень і публікацій. Сутність «репутаційного менеджменту» у вітчизняній науковій літературі певний час вважалося суперечним через низький рівень динамічності репутації вітчизняних підприємств. Також існували сумніви щодо ефективності впливу системи менеджменту на її рівень. Проблематику розвитку репутаційного менеджменту за умов діджиталізації досліджували такі науковці, як Даулінг Г. [7], Дерев'янко О.Г. [8, с. 5-18], Завербний А.С. [10], Кузнєцова Л.В. [9], Ломага Ю. [10], Помянська Н.Ю. $[15$, с. 57-61], а також інших. Діджиталізацію, цифровізацію в національній економіці досліджували такі вчені як Войнаренко М. П. [2, с. 18-24], Грибіненко О. [4, с. 35-37], Гудзь О. [5, с. 18-24], Коляденко С. В. [11, с. 106-107], Коробка С.В. $[12$, с. 88-96], Король С., Польовик Є. [13, с. 67-73], Скоробогата Л. В. [2, с. 18-24], Федюнін С., Щербина В. [5, с. 18-24] та багато інших. Дослідження розвитку репутаційного менеджменту за умов діджиталізації аналізували такі фрахівці як Верба В.А., Гайдамака Ю. М. [1], Гуренко А., Гашутіна О. [6, с. 739-745] та інші.

Виділення невирішених раніше частин загальної проблеми. В той же недостатньо уваги приділено євроінтеграційним аспектам (позитивного/негативного впливу) на розвиток репутаційного менеджменту при діджиталізації вітчизняної економіки.

Формулювання цілей статті (постановка завдання). Основними цілями (завданнями) статті виступають дослідження перспектив євроінтеграційного розвитку репутаційного менеджменту вітчизняних підприємств за умов діджиталізації (цифровізації).

Виклад основного матеріалу дослідження. Аналізуючи розвиток репутаційного менеджменту в Україні за умов діджиталізації, потрібно констатувати що обидва елементи (репутація, діджиталізація) $є$ достатньо новими для економіки нашої країни. Тому потребують як детального вивчення (дослідження) так і адаптування до умов, національних особливостей економіки. Перед дослідженням поняття діджиталізації аналізованої нами системи (репутаційного менеджменту) доцільно зазначити, що вагомі зміни, яких зазнає наше суспільство протягом останніх двох з половиною років вносять суттєві корективи до діяльності, устрої населення всього світу тощо.

Одночасно це призводить і до змін економічних процесів, їх подальшому транссрормуванню. Різкі обмеженості пересування, комунікування сприяли активізуванню процесу діджиталізації. Виникає деякий рівень Internet-залежності спілкування, придбання товарів (послуг, робіт), яке досить часто здійснюється в «online»-режимі. У зв'язку із вказаними обставинами власникам вітчизняних підприємств потрібно намагатися переймати досвід провідних підприємств, ТНК йти “в ногу з часом", активно впроваджуючи діждиталізацію до повсякденної виробничо-господарської діяльності [12, с. 88-89]. Враховуючи, що сутність поняття «репутація» можна трактувати в якості «неліквідного нематеріального активу довготривалого, багатоцільового характеру експлуатування (має споглядально-вартісну природу) стейкхолдерів, виступає важелем 
для взаємоузгодження інтересів та підприємства їх щодо забезпечення достатніх рівнів конкурентоспроможності, економічної безпеки тощо» [3, с. 313-318], з цієї точки зору в динамічних сучасних умовах, якщо керівництво підприємства не виявляє активність, мобільність і неорієнтоване виключно на своїх клієнтів, то таке підприємство суттєво втрачає репутації, просто «перестає» існувати для стейкхолдерів тощо. Саме тому система репутаційного менеджменту покликана залишати підприємство «в тренді», максимізувати його прибуток, мінімізувати витрати тощо [12, с. 88]. Формувати ефективну систему репутаційного менеджменту сприяє діджиталізація. Окрім того циорровий репутаційний менеджмент виступає новим науковим напрямком. Саме у його контексті фрормується сучасна інфрормаційна політика за динамічних умов глобалізування (в т.ч. і євроінтегрування). За сучасних ринкових умов процес діджиталізації виступив одним із визначальних чинників для економічного розвитку (зростання) вітчизняних підприємств, усього суспільства загалом. У програші залишилися ті, хто цього поки не усвідомив до кінця, не зареготав вчасно на дані виклики та не скористався потенційними можливостями змін. Адже динамічність зовнішнього середовища, зокрема технологічне транссрормування, посилення значимості інорормацій- них процесів, срормування все нових запитів (потреб) споживання, зумовлюють активний розвиток діджиталізації усієї світової спільноти. Діджиталізація, цифрова культура $€$ наслідком активного, революційного розвитку сучасних технологій (інновацій) в економіці, управлінні (менеджменті). Саме вони формують сучасні концепції менеджменту. Розвиток цифррового менеджменту в Україні покликаний поглиблювати та розширювати значимість науково-категоріальних форм цифррового дискурсу, що сприятиме формуванню креативних особистостей (в т.ч. й інституцій) як ключових інтелектуально-креативних ресурсів цілого суспільства [19]. Протягом останніх років, пов'язаних із проблемами пандемії, ії наслідків перспектива розвитку корпоративної репутації була невизначеною в цілому світі. Однак, за рейтингуванням топ-100 світових компаній (за індикатором рівня репутації), виявилося (див. рис. 1), що позиції стали найміцнішими за всі попередні роки. Це відбулося незважаючи на численні виклики 2020-2021 рр. [14]. Рейтинг був сорормований Global RepTrak, яка $€$ провідною світовою компанією з питань репутації та статистики.

У 2021 р. 100 найкращих (топових) світових компаній досягли значення «сильного» (strong) глобального рейтингу репутації, що становив аж 74,9 бали у порівнянні із 73,1 пунк-

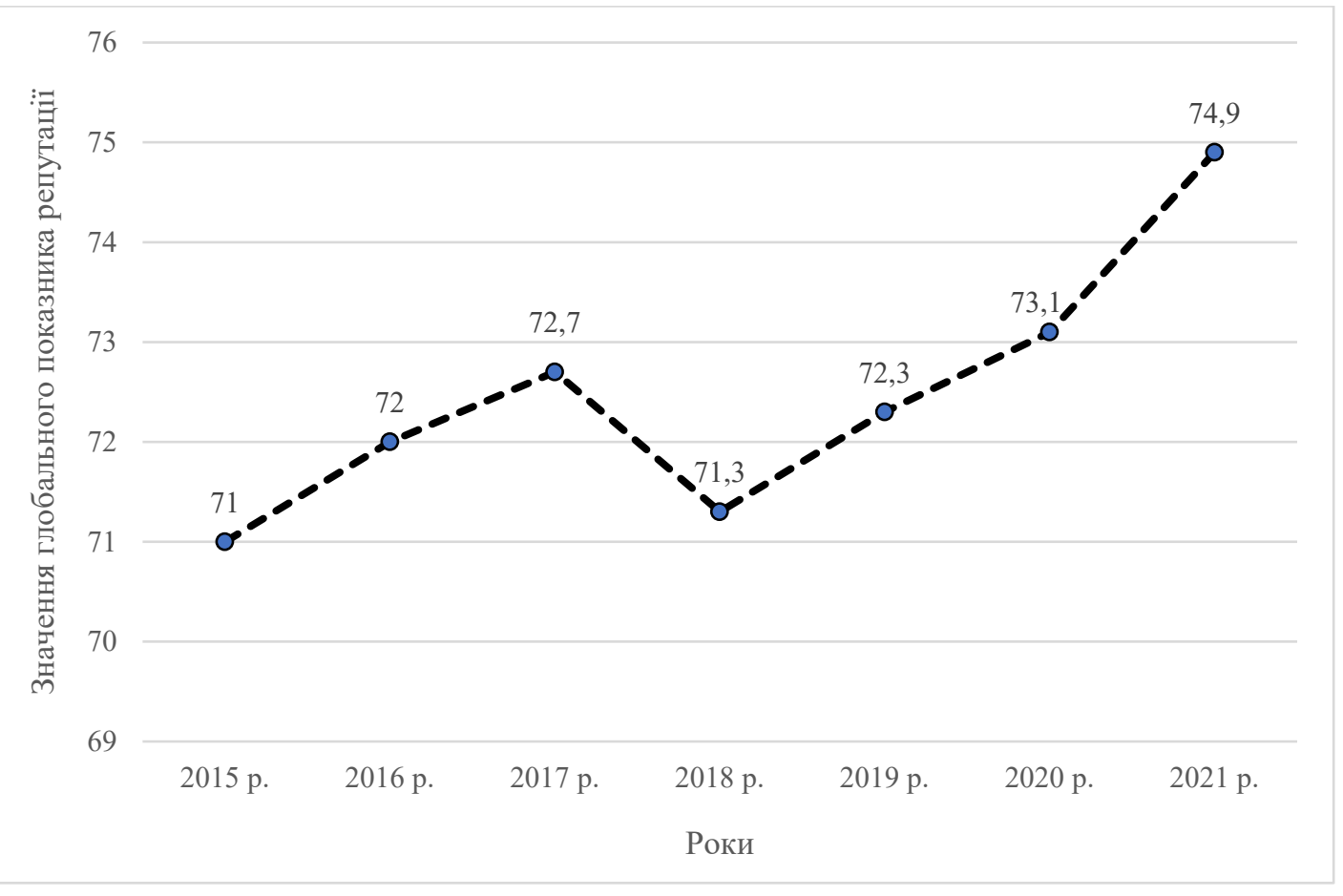

Рис. 1. Динаміка глобального показника репутації 100 провідних, найбільш авторитетних компаній світу за 2015-2021 рр. 


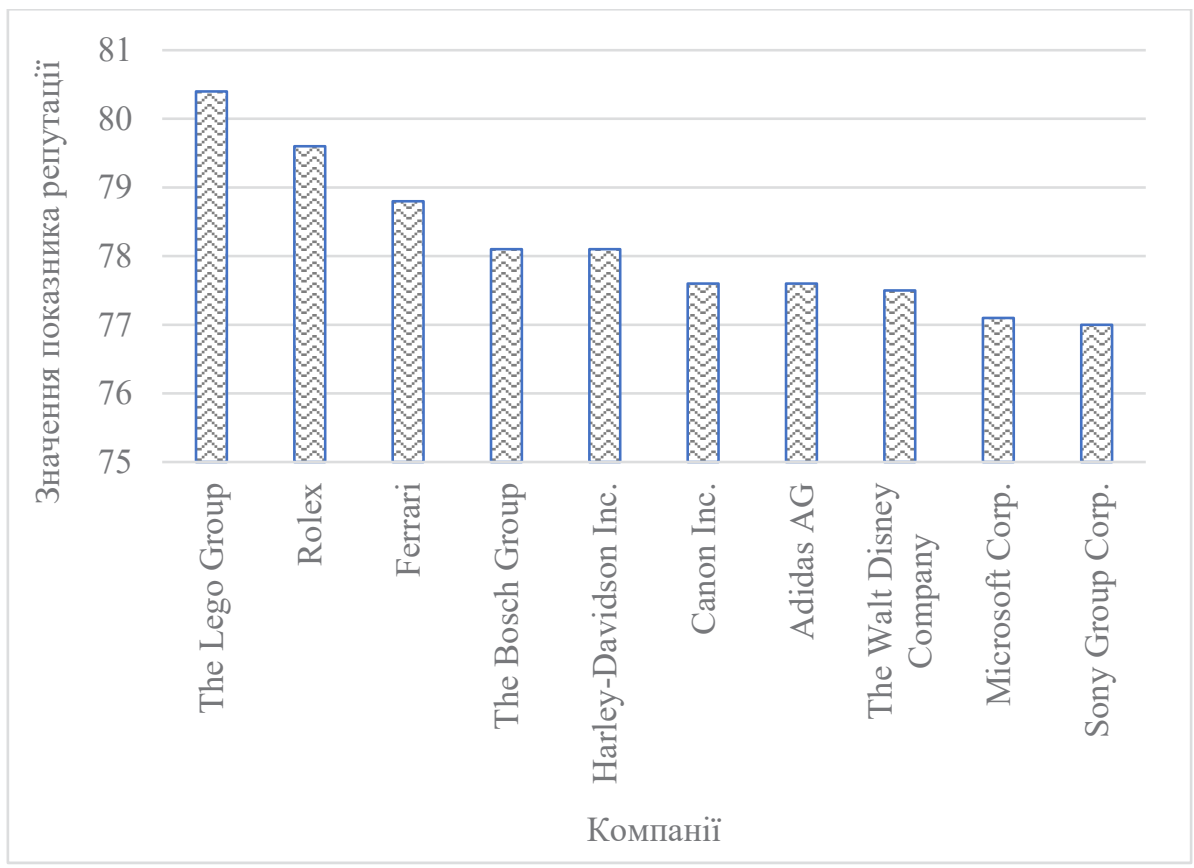

Рис. 2. Значення глобальних показників репутації у 10 найавторитетніших компаній світу у 2021 рр.

Джерело: [14]

тами за 2020 р. Це аж на 2,5\% більше, ніж у 2020 р. Глобальний показник/індикатор репутації досяг у 2021 р. свого найвищого рівня за всі попередні періоди. Збереглася позитивна тенденція із 2018 р. [14].

Приріст корпоративної (ділової) репутації в цілому світі (зокрема й передусім в провідних компаніях) засвідчив те, що лідери 2021 р. (рис. 2) не тільки вчасно реагували на кризові умови, але одночасно ефективно повідомляли про свої відповіді цим викликам своїм зацікавленим сторонам (стейкхолдерам). За рахунок цього компанії-лідери сприятимуть підвищенню власного рівня репутації і стратегічно отримають ще більший його приріст, захоплюючи власними досягненнями все більшу аудиторію [14]. А от для 10 провідних, найбільш авторитетних компаній світу за 2015-2021 рр. індикатор репутації становив значно вище значення у порівнянні із середньозваженим значенням для 100 провідних компаній (рис. 2) [14].

Згідно із цьогорічним рейтингом сфрормованим Global RepTrak, в топ-10 репутаційних світових лідерів потрапили такі компанії: The Lego Group, Rolex, Ferrari, The Bosch Group, Harley-Davidson Inc., Canon Inc., Adidas AG, The Walt Disney Company, Microsoft Corp., Sony Group Corp. (рис. 2) [14]. Прослідковується прямий взаємозв'язок між позитивною тенденцією рівня корпоративної репутації і високими продажами, прибутковістю тощо [10]. Згідно із проведеними дослідженнями Global RepTrak, 78\% всіх споживачів хочуть купувати продукцію/послуги/роботи у підприємств із високим рівнем репутації, а $70 \%$ респондентів прагнуть працювати саме в них, $64 \%$ готові надавати підтримку в кризових умовах [14]. Вітчизняним керівникам потрібно враховувати, що системи репутаційного менеджменту суттєво відрізняються використанням традиційних методів та цифрових технологій (приміром Інтернет мережі) (табл. 1).

Управління репутацією за допомогою використання цифрових технологій (зокрема й в мережі Інтернет) являє собою практику із формування суспільного сприйняття організації/підприємства, спосіб впливати на те, як люди сприйматимуть організацію, іiї бізнес в мережі Інтернет. Репутація вітчизняного підприємства, яка формується не лишень виключно «оff-line», але й «on-line», повинна передбачатися при складанні бюджету шляхом планування витрат на поточний моніторинг задля запобігання появі/поширенню негативу. Це має відбуватися на противагу точковому фрінансування для ліквідування вже наявних негативних наслідків впливу зовнішнього середовища.

Висновки. За сучасних високодинамічних умов економічної нестабільності особливої ваги набули потенційні можливості щодо під- 
Таблиця 1

\section{Порівняльна характеристика інформаційного забезпечення систем репутаційного менеджменту за допомогою використання традиційних методів та цифрових технологій}

\begin{tabular}{|c|c|}
\hline $\begin{array}{c}\text { Система управління } \\
\text { репутацією організації } \\
\text { за допомогою традиційних методів }\end{array}$ & $\begin{array}{c}\text { Система управління репутацією } \\
\text { організації із використанням сучасних } \\
\text { цифрових технологій } \\
\end{array}$ \\
\hline $\begin{array}{l}\text { Достатня швидкість розповсюдження } \\
\text { інорормації про організацію }\end{array}$ & Миттєве/блискавичне поширення інфрормації \\
\hline $\begin{array}{l}\text { Великі розміри затрат необхідних для } \\
\text { реалізування процесів із фрормування, } \\
\text { збирання, систематизування, аналізування, } \\
\text { дослідження тощо. } \\
\text { Складність комплексного охоплення всього } \\
\text { інфрормаційного масиву }\end{array}$ & $\begin{array}{l}\text { Незначні витрати для моніторингу. } \\
\text { Наявність програмного забезпечення } \\
\text { для пришвидшення процесу моніторингу } \\
\text { інфрормаційних масивів }\end{array}$ \\
\hline $\begin{array}{l}\text { Процеси сист } \\
\text { потребують з। }\end{array}$ & й наявність інфрормації у відкритому \\
\hline ся серед & $\begin{array}{l}\text { ия інфрормації відбувається серед } \\
\text { ььйонів осіб }\end{array}$ \\
\hline $\begin{array}{l}\text { Поширюється лишень в межах однієї країни } \\
\text { (переважно) }\end{array}$ & в межах країни, але легко \\
\hline $\begin{array}{l}\text { Вільний доступ до поширюваної інформації } \\
\text { упродовж досить короткого терміну. Потім } \\
\text { її знайти є досить важко, без застосування } \\
\text { різноманітних засобів діджиталізації }\end{array}$ & $\begin{array}{l}\text { Вільний доступ до інорормації впродовж } \\
\text { тривалого терміну, головне без обмежень } \\
\text { в часі отримання (цілодобово) }\end{array}$ \\
\hline
\end{tabular}

вищення рівня ефрективності фрункціонування української економіки шляхом активізування процесів діджиталізації. Для України розвиток процесів діджиталізації володіє реальними перспективами для модернізування економіки, покращення виробничо-технологічної структури, забезпечення активної участі в інноваційній економіці, подолання сучасного кризового стану тощо. Окрім того, запровадження сучасних інорокомунікаційних технологій виступатиме напрямком підвищення рівня репутації підприємств, рівня їх конкурентоспроможності, зростання гнучкості за умов економічної нестабільності, конкурентної боротьби із іноземними підприємствами внаслідок глобалізування (в т.ч. Євроінтегрування).

\section{СПИСОК ВИКОРИСТАНИХ ДЖЕРЕЛ:}

1. Верба В.А., Гайдамака Ю.М. Маркетингові інструменти посилення репутації фармацевтичних компаній в умовах діджиталізації. Ефрективна економіка. 2020. № 11. URL: http://www.economy.nayka.com.ua/ ?op $=1 \& z=8639$

2. Войнаренко М.П., Скоробогата Л.В. Мережеві інструменти капіталізації інформаційно інтелектуального потенціалу та інновацій. Вісник Хмельницького національного університету. Економічні науки. 2015. № 3. T. 3. C. $18-24$.

3. Грабчак В.І. Сутність поняття «репутація підприємства» та її складових. Глобальні та національні проблеми економіки. 2016. № 10. С. 313-318.

4. Грибіненко О. Діджиталізація економіки в новій парадигмі цифррової трансформації. Міжнародні відносини. Серія «Економічні науки». 2018. № 16. С. 35-37.

5. Гудзь О., Федюнін С., Щербина В. Диджиталізація, як конкурентна перевага підприємств. Економіка. Менеджмент. Бізнес. 2019. № 3. С. 18-24.

6. Гуренко А., Гашутіна О. Напрями розвитку систем управління в умовах діджіталізації бізнесу в Україні. Економіка і суспільство. 2018. № 19. С. 739-745.

7. Даулинг Г. Репутация фирмы: создание, управление и оценка эфффективности / пер. с англ. Москва : ИНФРА-М, 2003. XXVI, 368 c.

8. Дерев'янко О.Г. Механізми впливу репутаційного менеджменту на бізнес-результати. Стратегія економічного розвитку України. 2018. № 42. С. 5-18. 
9. Ділова репутація банків: цифрові виклики та управління : монографрія / За редакцією Л.В. Кузнєцової. Харків : «Діса Плюс», 2020. 327 с.

10. Завербний А., Ломага Ю. Проблеми та перспективи фрормування репутаційного менеджменту українськими підприємствами і організаціями з метою підвищення їх конкуренції. Економіка та суспільство. 2020. № 22. URL: https://economyandsociety.in.ua/index.php/journal/article/view/93

11. Коляденко С.В. Цифрова економіка: передумови та етапи становлення в Україні і у світі. Економіка. Фінанси. Менеджмент. 2016. № 6. С. 106-107.

12. Коробка С.В. Діджиталізація підприємницької діяльності. Вісник Харківського національного університету імені В.Н. Каразіна. Серія «Економічна». 2021. № 100. С. 88-96.

13. Король С., Польовик Є. Діджиталізація економіки як фактор професійного розвитку. Modern Economics. 2019. № 18. С. $67-73$.

14. Офіційний сайт RepTrak. URL: https://www.reptrak.com/rankings/

15. Помянська Н.Ю. Управління діловою репутацією на синергетичних засадах. Науковий вісник Херсонського державного університету. 2014. Випуск 9. Частина 4. С. 57-61.

\section{REFERENCES:}

1. Verba V.A., Haidamaka Y.M. (2020) "Marketing tools to strengthen the reputation of pharmaceutical companies in the context of digitalization". Efektyvna ekonomika [Online], vol. 11. Available at: http://uww.economy.nayka.com.ua/ ?op $=1 \& z=8639$

2. Vojnarenko M.P., Skorobogata L.V. (2015) Merezevi instrumenty kapitalizacii informasijno intelektualnogo potencialu ta inovacij [Network tools for capitalization of information intellectual potential and innovations]. Visnyk Khmelnyckogo nacionalnogo universytetu, 3.3, 18-24. (in Ukrainian)

3. Grabchak V.I. (2016) Sytnist poniatia «reputaciya pidpryjemstva» ta ii skladovykh [The essence of the concept of "reputation of the enterprise" and its components]. Globalni ta nacionalni problemy ekonomiky, 10, 313-318. (in Ukrainian)

4. Grybinenko O. (2018) Didzytalizacija ekonomiky v novij paradygmi cyfrovoi transformacii [Digitalization of the economy in a new paradigm of digital transformation]. Miznarodni vidnosyny, 16, 35-37. (in Ukrainian)

5. Gudz O., Fediunin S., Shczerbyna V. (2019). Didzytalizacija, jak konkurentna perevaga pidpryjamstv [Digitalization as a competitive advantage of enterprises]. Ekonomika. Menedzment. Biznes, 3, 18-24. (in Ukrainian)

6. Gurenko A., Gashutina O. (2018) Napriamy rozvytku system upravlinia v umovakh didzytalizacii biznesu v Ukraini [Directions of development of management systems in the conditions of digitalization of business in Ukraine]. Ekonomika i suspilstvo, 19, 739-745. (in Ukrainian)

7. Dauling G. (2003) Reputacia firmy: sozdanie, upravlenie i ocenka efektivnosti [Company reputation: creation, management and evaluation of efficiency]. Moscow: INFRA-M, XXVI, 368. (in Russian)

8. Derevianko О.Г. (2018) Mechanizmy vplyvu reputacijnogo mendzmentu na biznes-rezultaty [Mechanisms of influence of reputation management on business results]. Strategija ekonomichnogo rozvytku Ukrainy, 42, 5-18. (in Ukrainian)

9. Dilova reputacija bankiv: cyfrovi vyklyky ta upravlinia: monographiia 2020 [Business reputation of banks: digital challenges and management: a monograph] / Kuznecova L.V. Kharkiv: «Disa Plius». (in Ukrainian)

10. Zaverbnyj A., Lomaga Yu. (2020) Problemy ta perspektyvy formyvannia reputacijnogo menedzmentu ukrinskymy pidpryjemstvamy i organizacijamy z metoju pivyshchennia jikh konkurencii [Problems and prospects of formation of reputation management by Ukrainian enterprises and organizations in order to increase their competition]. Ekonomika ta suspilstvo, 22. Available at: https://economyandsociety.in.ua/index.php/journal/article/view/93

11. Koliadenko S.V. (2016) Cyfrova ekonomika: peredumovy ta etapy stranovlennia v Ukraini i u sviti [Digital economy: preconditions and stages of formation in Ukraine and in the world]. Ekonomika. Phinansy. Menedzment, 6, 106-107. (in Ukrainian)

12. Korobka S.V. (2021) Didzytalizacija pidpryjemnyckoi diyalnosti [Digitalization of entrepreneurial activity]. Visnyk Kharkivskogo nacionalnogo universytetu, 100, 88-96. (in Ukrainian)

13. Korol S., Polovyk Ye. (2019) Didzytalizacija ekonomiky yak faktor profesijnogo rozvytku [Digitalization of the economy as a factor of professional development]. Modern Economics, 18, 67-73. (in Ukrainian)

14. RepTrak. Available at: https://www.reptrak.com/rankings/

15. Pomians'ka N.Yu. (2014) Upravlinnya dilovoyu reputaciyeyu na sinergetichnih zasadah [Business reputation management on a synergistic basis]. Naukoviy visnik Hersons`kogo derzavnogo universitetu, 9, part 4, pp. 57-61. (in Ukrainian) 